\title{
Disease knowledge and preferences for disclosure of information in patients with rheumatoid arthritis
}

\section{Conocimiento de la enfermedad y preferencias de divulgación de información en pacientes con artritis reumatoide}

\author{
DOI: $10.46814 / 1 a j d v 3 n 6-019$
}

Recebimento dos originais: 01/11/2021

Aceitação para publicação: 09/12/2021

\author{
Rafael Pauletti Gonçalves \\ Academic of Medicine at Pontifical Catholic University of Sao Paulo \\ E-mail: rafapauletti@uol.com.br \\ Maria Carolina Diana Simões \\ Academic of Medicine at Pontifical Catholic University of Sao Paulo \\ E-mail: caro.diana@gmail.com \\ Renata Viana Pereira \\ Academic of Medicine at Pontifical Catholic University of Sao Paulo \\ E-mail: rezinha_viana@ig.com.br \\ Amine Barbella Saba \\ Resident of Pediatry at Santa Casa of Sao Paulo \\ E-mail: aminebsaba@yahoo.com.br

\section{Gilberto Santos Novaes} \\ Professor, Head of Rheumatology at Medical Clinical Department at Pontifical Catholic \\ Medical Clinical Departament \\ Braz Laino, 181 - Jd Emília - Sorocaba - SP \\ E-mail: gnovaes52@gmail.com
}

\begin{abstract}
Objectives: To verify the level of knowledge about rheumatoid arthritis (RA) and the patient's preferences for disclosure of information by the physician in patients with RA, we compared with a control group of patients without RA.

Methods: We evaluated 30 patients diagnosed with RA, according to the ACR criteria, and 30 patients with other diseases pared for age, gender, level of education, and disease duration followed in an OutPatient Service. Clinical-demographic data as age, gender, level of education, and disease duration were obtained from both groups. We applied questionnaires to evaluate the level of knowledge about RA (10 questions) with answers yes or no, and the patient's preference for disclosure of information by the physician (4 questions) in a Likert scale from a) strongly agree to e) strongly disagree to both groups. The questionnaires were validated for Portuguese by the method of translation and retranslation. The Ethical Committee at the Pontifical Catholic University approved the study, and we obtained informed consent from all patients. When appropriat-ed, statistical analysis of the data included the chi-square test and student's t-test. The significance level was 0.05 .

Results: Over 30 patients with RA, 27 patients (90\%) were women, the mean age was 50.8 years old, with a mean of 3.03 years on school, and mean disease duration of 10.6 years. The knowledge about
\end{abstract}




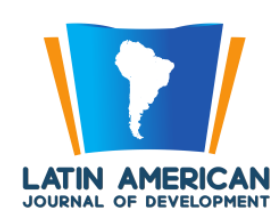

RA as a mean reached 5.36 points in 10 as a correct answer in RA patients and 5.13 in controls. Concerning the patient's preference for disclosure of information by the physician, the results varied between $23.3 \%$ and $90 \%$ in the answers strongly agree or agree in the group of RA patients and $6.6 \%$ to $90 \%$ in controls. In a specific question about "patients with RA should not play a role in managing their disease because the physician is the one in charge," $56.6 \%$ of RA patients agreed, and $46,6 \%$ of controls too. Only one question about patient's preference for disclosure of information by the physician "When there is more than one way to treat a problem, I should be told about each one" there was a trend to differ between the controls and the RA patients $(\mathrm{p}=0.06)$. The analysis of the results showed no statistical difference in answers to the questionnaires between RA patients and controls.

Conclusion: Our results showed that RA patients, compared to control patients with other nonrheumatic diseases, do not show differences to the level of knowledge about rheumatoid arthritis (RA) and the patient's preferences for disclosure of information by the physician.

Keywords: rheumatoid arthritis, disclosure of information, knowledge of disease.

\section{RESUMEN}

Objetivos: Verificar el nivel de conocimiento sobre la artritis reumatoide (AR) y las preferencias del paciente en cuanto a la divulgación de información por parte del médico en pacientes con AR, comparado con un grupo control de pacientes sin AR.

Métodos: Se evaluaron 30 pacientes diagnosticados de AR, según los criterios de la ACR, y 30 pacientes con otras enfermedades, a los que se les comparó la edad, el sexo, el nivel de estudios y la duración de la enfermedad, seguidos en un Servicio de Consultas Externas. De ambos grupos se obtuvieron datos clínico-demográficos como la edad, el sexo, el nivel de estudios y la duración de la enfermedad. Se aplicaron cuestionarios para evaluar el nivel de conocimiento sobre la AR (10 preguntas) con respuestas de sí o no, y la preferencia del paciente por la divulgación de información por parte del médico (4 preguntas) en una escala Likert desde a) muy de acuerdo hasta e) muy en desacuerdo a ambos grupos. Los cuestionarios fueron validados para el portugués por el método de traducción y retraducción. El Comité Ético de la Pontificia Universidad Católica aprobó el estudio y se obtuvo el consentimiento informado de todos los pacientes. Cuando fue apropiado, el análisis estadístico de los datos incluyó la prueba de chi-cuadrado y la prueba t de student. El nivel de significación fue de 0,05 .

Resultados: De los 30 pacientes con AR, 27 (90\%) eran mujeres, la edad media era de 50,8 años, con una media de 3,03 años de escolarización y una duración media de la enfermedad de 10,6 años. Los conocimientos sobre la AR alcanzaron una media de 5,36 puntos sobre 10 como respuesta correcta en los pacientes con AR y de 5,13 en los controles. En cuanto a la preferencia del paciente por la divulgación de información por parte del médico, los resultados variaron entre el 23,3\% y el 90\% en las respuestas muy de acuerdo o de acuerdo en el grupo de pacientes con AR y del 6,6\% al $90 \%$ en los controles. En una pregunta específica sobre "los pacientes con AR no deberían desempeñar un papel en la gestión de su enfermedad porque el médico es el que manda", el 56,6\% de los pacientes con AR estuvieron de acuerdo, y el 46,6\% de los controles también. Sólo en una pregunta sobre la preferencia de los pacientes por la divulgación de información por parte del médico "Cuando hay más de una forma de tratar un problema, se me debería informar de cada una de ellas" hubo una tendencia a diferir entre los controles y los pacientes con $\mathrm{AR}(\mathrm{p}=0,06)$. El análisis de los resultados no mostró diferencias estadísticas en las respuestas a los cuestionarios entre los pacientes con AR y los controles.

Conclusión: Nuestros resultados mostraron que los pacientes con AR, en comparación con los pacientes de control con otras enfermedades no reumáticas, no muestran diferencias en el nivel de conocimiento sobre la artritis reumatoide (AR) y las preferencias del paciente para la divulgación de información por parte del médico.

Palabras clave: artritis reumatoide, divulgación de información, conocimiento de la enfermedad. 


\section{INTRODUCTION}

Rheumatoid arthritis (RA) is a chronic, systemic, autoimmune, and inflammatory disease characterized by the involvement of multiple joints with their destruction and consequent mechanical and physical disability. In this context, the health education of RA patients is essential to the psychic well-being of patients and to increase adherence to the treatment and allow the patient to participate in the treatment decisions that minimize the impact of the disease. Patient knowledge about the disease, particularly in RA, is an essential element of treatment, allowing the patients with RA to take care of themselves and make decisions about their health (1). It depends on how much the disease will change their lives and how to cope with important aspects of the disease. In relation to the disease activity, patient knowledge and education about their disease have no benefit about this aspect of the disease (2). In a study in Hospital care, only $1.5 \%$ of patients with RA were considered aware of their condition when questioned about symptoms, possible complications, and RA treatment (3). An essential aspect of medical patient communication is the disclosure of treatment-related risks and how much information has to be disclosed to the patient about their disease. Studies have demonstrated that wellinformed patients do not have an increase in the frequency of adverse effects of medication or an increase in the level of anxiety in well-informed patients compared with controls (4,5). An extensive discussion about the varied treatment options currently available for RA is critical today in the care of rheumatic patients. This study will verify the level of knowledge about rheumatoid arthritis (RA) and the patient's preferences for disclosure of information by the physician in patients with RA compared with a control group of patients without RA.

\section{METHODS}

We interviewed and analyzed a sample of 30 patients diagnosed with RA, according to the ACR classification criteria (6), and 30 patients as the control group with other non-rheumatic diseases like arterial hypertension (50\% of patients), diabetes mellitus (30\%) and other diseases (20\%). They were in clinical follow-up at the Rheumatology Out-patient Service of the Sorocaba Hospital/Pontifical Catholic University of Sao Paulo (PUC/SP). Both groups we paired for age, gender, level of education, and disease duration. The Ethical Committee of the PUC/SP approved the study, and we obtained informed consent from all patients. We collect clinical and demographic data such as gender, age, years at school, and disease duration from both groups. We applied two questionnaires to both groups to evaluate the level of knowledge about RA (10 questions) with the answer yes or no; and the patient's preference for disclosure of information by the physician (4 questions) in a Likert scale from: a) strongly agree; b) agree; c) neither agree nor disagree; d) disagree; e) strongly disagree. The questionnaires were validated for Portuguese by the method of translation and re-translation. The level 
of knowledge about RA we obtained with the following questions: 1)There is only a single therapy for all RA patients; 2) All RA patients have a bad prognosis; 3) The neck is the most commonly affected área of the spine in patients with RA; 4) RA is caused by cold weather, inadequate nourishment and humidity; 5) Patients with RA should not play a role in the management of their disease because the physician is the one in charge; 6) RA and osteoporosis are the same disease; 7) RA can produce dryness in the eyes and mouth; 8) Patients with RA should include all kinds of food in their meals but must avoid meat; 9) RA never compromises the lungs; 10) To confirm the diagnosis of RA, it is necessary to perform some blood tests. We considered a positive result on knowledge of RA as five or more right answers in 10 questions (7). The patient's preferences for disclosure of information we obtained with the following questions: 1) Even if the news is bad I should be well informed; 2) It is important for me to know all the side effects of my medications; 3 ) When there is more than one way to treat a problem, I should be told about each one; 4) I should be given information only when I ask for it. Each question of disclosure preferences was evaluated apart (8). When appropriated, statistical analysis of the data included the chi-square test and student's t-test. The significance level was 0.05 .

\section{RESULTS}

Over 30 patients with RA 27 patients (90\%) were women, the mean age was 50.8 years old, with a mean of 3.03 years at school, and mean disease duration of 10.6 years. We observed no statistical difference in these items between RA and control patients and both groups for these variables. The knowledge about RA reached a mean of 5.36 points in RA patients and 5.13 in controls $(\mathrm{p}=0.48)$. Question 5, "Patients with RA should not play a role in the management of their disease because the physician is the one in charge," has $56.6 \%$ of yes for RA patients and $46.6 \%$ in the control group $(p=0.79)$. As a whole, in the level of knowledge of RA, both groups do not show a difference $(p=0.48)$. About the patient's preference for disclosure of information by the physician, the results varied between $23.3 \%$ and $90 \%$ on strongly agree or agree $(\mathrm{a}+\mathrm{b})$ in RA patients and $6.6 \%$ to $90 \%(\mathrm{a}+\mathrm{b})$ in controls. In a specific question, number 3, about "When there is more than one way to treat a problem, I should be told about each one," $83.3 \%$ of RA patients strongly agree or agree, and $73.3 \%$ of controls too. Only in question number 3, was there a trend to statistical difference from the controls and the RA patients $(\mathrm{p}=0.06)$. Question number 4, “When there is more than one way to treat a problem, I should be told about each one, " has a low agreement $(\mathrm{a}+\mathrm{b})$ with $23.3 \%$ of the $\mathrm{a}+\mathrm{b}$ in RA patients and a less agreement in the control group with $6.6 \%$ of the $a+b$. Table 1 below shows the analysis of demographic and clinical data and the statistical data from the level of knowledge about RA and the patient's preferences for disclosure of information by the physician in patients with RA and controls. 
Table 1. Analysis of clinical and demographic features and level of knowledge about rheumatoid arthritis (RA) and the patient's preferences for disclosure of information by the physician in patients with RA compared with a control group of patients without RA

\begin{tabular}{lccc}
\hline Rheumatoid Arthritis & Control Patients & Statistical analysis & \\
\hline Age, years & 50.8 & 53.3 & $\mathrm{p}=0.74$ \\
Gender, \% women & 90 & 86.6 & $\mathrm{p}=0.68$ \\
$\begin{array}{l}\text { Disease duration, years } \\
\text { Education, }\end{array}$ & 10.6 & 13.7 & $\mathrm{p}=0.65$ \\
years at school & 3.3 & 5.6 & $\mathrm{p}=0.11$ \\
Disease knowledge, & 5.36 & 5.13 & \\
number of right answers & & & $\mathrm{p}=0.48$ \\
Preferences of disclosure, & & & \\
Q question, \% patients & 86.6 & 90 & \\
Q1 & 90 & 76.6 & $\mathrm{p}=0.65$ \\
Q2 & 83.3 & 73.3 & $\mathrm{p}=0.56$ \\
Q3 & 23.3 & 6.6 & $\mathrm{p}=0.06$ \\
Q4 & & $\mathrm{p}=0.17$ \\
\hline
\end{tabular}

Values are expressed as mean.

The analysis of the results showed no statistical difference in answers to the questionnaires between RA patients and controls.

\section{DISCUSSION}

In this study of disease knowledge about RA and patients' preferences of disclosure of information by the physician, we applied questionnaires to evaluate these topics to RA patients and controls. The knowledge level, considered good with more than 50\% correct answer, showed no difference between RA and controls. Age, gender, level of education, and disease duration were the same in both groups and did not interfere in patients' answers regarding disease knowledge or preferences of disclosure of information. The specific question about the patient's involvement in the management of their disease surprisingly showed that more than $50 \%$ of RA patients considered that they should not be involved in the management of their disease. The RA knowledge level in RA patients and controls does not differ. Maybe it demonstrates that only having the disease does not increase their knowledge of their disease in the patient.

Regarding patients' preferences of disclosure of information by the physician, both RA patients and controls did not show a difference in the four questions proposed. In a specific question about treatment choices, there is a trend in RA patients to consider being informed about the various treatment options than in the control group. As a whole, there was no difference in answers to the questionnaires between RA patients and control patients. As Pytel \& Wrzosek (1) described, people with higher education were more interested in obtaining information about RA, and women had more knowledge about RA than men. In this study, the patients' primary disease knowledge source came from 
physicians, physiotherapists, or nurses. Another study by Pérez S et al. (9) showed that RA patients were very interested in knowing about RA, and high functional impairment increased this educational need. The rheumatologist is the primary source of information for the patients. The question about the role of education in RA disease in the outcome of the RA patients is controversial. No significant differences were found in radiographic changes and quality of life (10).

Nonetheless, better disease control of RA may be achieved by improving patient knowledge of the disease (11). The need for information and decision-making was higher in women than in men and younger age, and greater knowledge of RA predicted a greater need for decision-making. However, the desire for involvement in treatment decision-making was significantly lower and did not correlate with the need for information (12). Our study has limitations, and caveats about the number of patients studied and be a transversal study. Future studies need to confirm our findings and improve the understanding of disease knowledge about RA and patients' preferences of disclosure of information by the physician.

\section{CONCLUSIONS}

Our results showed that RA patients, compared to control patients with other non-rheumatic diseases, do not show differences in the level of knowledge about rheumatoid arthritis (RA) and the patient's preferences for disclosure of information by the physician. 


\section{REFERENCES}

1. Pytel A, Wrzosek Z. Estimation of patient knowledge on rheumatoid arthritis in the range of their own disease - preliminary study. Adv Clin Exp Med 2012;21:343-51.

2. Brus HL, Taal E, van de Laar MA, Rasker JJ, Wiegman O. Patient education and disease activity: a study among rheumatoid arthritis patients. Arthritis Care Res 1997;10:320-4.

3. Zarghoona K, Salim B, Nasim A, Malik S. Patient's knowledge on rheumatoid arthritis - a study at a tertiary care hospital. J Pak Med Assoc 2017;67:256-60.

4. Howland JS, Baker MG, Poe T. Does patient education cause side effects? A controlled trial. J Fam Pract 1990;31:62-4.

5. Lankton JW, Batchelder BM, Ominsky AJ. Emotional responses to detailed risk disclosure for anesthesia, a prospective, randomized study. Anesthesiology 1977;46:294-6.

6. Arnett FC, Edworthy SM, Bloch DA, McShane DJ, Fries JF, Cooper NS et al. The American Rheumatism Association 1987 revised criteria for the classification of rheumatoid arthritis. Arthritis Rheum 1988;31:315-24.

7. Cadena J, Anaya JM. Education for patients with rheumatoid arthritis: is it worth it?. Arthritis Rheum 2003;49:738-40.

8. Fraenkel L, Bogardus S, Concato J, Felson D. Preference for disclosure of information among patients with rheumatoid arthritis. Arthritis Care Res 2001;45:136-9.

9. Pérez S, Cruz MS, Sosa J, Kohan P, Medina M, Klajn D. Evaluation of the educational needs in Argentine patients with rheumatoid arthritis using the SpENAT questionnaire. Rheumatol Clin 2020;16:386-90.

10. Helliwell PS, O’Hara M, Holdsworth J, Hesselden A, King T, Evans P. A 12-month randomized controlled trial of patient education on radiographic changes and quality of life in early rheumatoid arthritis. Rheumatology 1999;38:303-8.

11. Kamruzzaman AKM, Chowdhury MR, Islam MN, Sultan I, Ahmed S, Sharin A et al. The knowledge level of rheumatoid arthritis patients about their disease in a development country. A study in 168 Bangladeshi RA patients. Clin Rheumatol 2020;39:1315-23.

12. Neame R, Hammond A, Deighton C. Need for information and for involvement in decision making among patients with rheumatoid arthritis: a questionnaire survey. Arthritis Rheum 2005;53:249-55. 